\title{
Development and Antibacterial Activity of Cashew Gum-Based Silver Nanoparticles
}

\author{
Patrick V. Quelemes ${ }^{1,2}$, Felipe B. Araruna ${ }^{1,3}$, Bruna E. F. de Faria ${ }^{4,5}$, Selma A. S. Kuckelhaus ${ }^{5}$, \\ Durcilene A. da Silva ${ }^{1}$, Ronaldo Z. Mendonça ${ }^{6}$, Carla Eiras ${ }^{1}$, Maria José dos S. Soares ${ }^{7}$ and \\ José Roberto S. A. Leite ${ }^{1,2, *}$
}

1 Biotec-Biodiversity and Biotechnology Research Center, Federal University of Piauí, Parnaíba, PI 64202020, Brazil; E-Mails: pquelemes@gmail.com (P.V.Q.); araruna@ufpi.edu.br (F.B.A.); durcileneas@yahoo.com.br (D.A.S.); carla.eiras.ufpi@gmail.com (C.E.)

2 Medical Plants Research Center, Federal University of Piaú, Teresina, PI 64049550, Brazil

3 Federal Institute of Education, Science and Technology of Piauí, Parnaíba, PI 64210260, Brazil

4 Laboratory of Forensic Ridgeology, Institute of Civil Identification of Police, II/PCDF, 70610200 DF, Brazil; E-Mail: bruna.unb@ hotmail.com

5 Laboratory of Cellular Immunology, School of Medicine, University of Brasília, Brasília, DF 70910900, Brazil; E-Mail: selmask@gmail.com

6 Laboratory of Parasitology, Butantan Institute, 05504900, São Paulo, SP, Brazil; E-Mail: zucatelli@butantan.gov.br

7 Department of Veterinary Morphophysiology, Federal University of Piauí, Teresina, PI 64049550, Brazil; E-Mail: mrsapijf@gmail.com

* Author to whom correspondence should be addressed; E-Mail: jrsaleite@gmail.com; Tel.: +55-86-3323-5846; Fax: +55-86-3323-5406.

Received: 26 November 2012; in revised form: 11 January 2013 / Accepted: 6 February 2013 / Published: 1 March 2013

\begin{abstract}
The present study describes the development of a green synthesis of silver nanoparticles reduced and stabilized by exuded gum from Anacardium occidentale L. and evaluates in vitro their antibacterial and cytotoxic activities. Characterization of cashew gum-based silver nanoparticles (AgNPs) was carried out based on UV-Vis spectroscopy, transmission electron microscopy and dynamic light scattering analysis which revealed that the synthesized silver nanoparticles were spherical in shape, measuring about $4 \mathrm{~nm}$ in size with a uniform dispersal. AgNPs presented antibacterial activity, especially against Gram-negative bacteria, in concentrations where no significant cytotoxicity was observed.
\end{abstract}


Keywords: silver nanoparticles; cashew gum; antibacterial activity; cytotoxicity

\section{Introduction}

The ability of pathogenic bacteria to resist antibacterial agents has evolved since the start of antimicrobial therapy and it still constitutes a serious problem in clinical practice; limiting the arsenal of drugs available and requiring the development of new substances to combat them [1-4]. In this context, inorganic agents have been considered excellent candidates for research because of their high antibacterial potential $[5,6]$. Among them, silver compounds and their derivatives are one of the most extensively studied, and a current focus of research involving this metal is the synthesis and evaluation of their antimicrobial activity in the form of nanoparticles [7-11].

Silver nanoparticles have been produced by different routes of synthesis. However, some of them appear to be unconcerned with environmental issues regarding the potential deleterious effect of some of their constituents, while at the same time presenting high levels of toxicity; this requires the development of nanoparticles using biocompatible and biodegradable materials, which is the purpose of "Green synthesis" [12-14]. Some of the reducing and/or stabilizing agents used for the production of silver nanoparticles by green synthesis that stand out are: microorganisms like bacteria and fungi [15-17], chitosan [18,19]; vegetable extracts [20,21]; seaweed [11,22] and natural gums [10].

Cashew gum is a natural product extracted with low cost and is an easily available source, the Anacardium occidentale L. tree, widely present in the northeastern part of Brazil. It is a non-toxic, complex heteropolysaccharide exuded either naturally or by making incisions in the trunk or the branches of the trees; it is seen as a yellowish resin. It is reported to contain: b-D-galactose (72\%), a-D-glucose (14\%), arabinose (4.6\%), rhamnose (3.2\%) and glucuronic acid (4.7\%) [23].

In this study the development of cashew gum-based silver nanoparticles (AgNPs), reduced and stabilized by gum exuded from Anacardium occidentale L., a natural, renewable and sustainable source, is presented. The cashew gum-based silver nanoparticles (AgNPs) were characterized by UV-Vis spectroscopy, Transmission Electron Microscopy (TEM) and Dynamic Light Scattering (DLS) analysis followed by evaluation of their antibacterial and cytotoxic activities.

\section{Results and Discussion}

Silver nanoparticles were formed by the reduction of $\mathrm{Ag}^{+}$into $\mathrm{Ag}^{0}$ with the addition of cashew gum $(0.3 \%)$ to a solution of $1 \mathrm{mM}$ of $\mathrm{AgNO}_{3}$. The colorless solution of $\mathrm{AgNO}_{3}$ turned yellowish in color, indicating the formation of silver nanoparticles. The formation of silver nanoparticles was monitored by UV-Vis absorption spectra at 300-600 $\mathrm{nm}$ where a band was detected at $420 \mathrm{~nm}$. The silver nanoparticle size, morphology and distribution were analyzed by TEM and DLS (Figure 1). 
Figure 1. (A) Gum exuded from the stem of the cashew (Inset: cashew gum purified); (B) UV-Vis absorption spectrum of the cashew gum-based AgNPs; the arrow indicates the maximum absorbance at $420 \mathrm{~nm}$ (Inset: Photography comparing the color of the solutions of $\mathrm{AgNO}_{3}$ and AgNPs); (C) Histogram showing the particle size distribution (4.38 $\left.\pm 0.07 \mathrm{~nm}\right)$ measured by Dynamic Light Scattering (DLS); (D) Transmission Electron Microscopy (TEM) image of cashew gum-based AgNPs (scale bar $50 \mathrm{~nm}$ ).
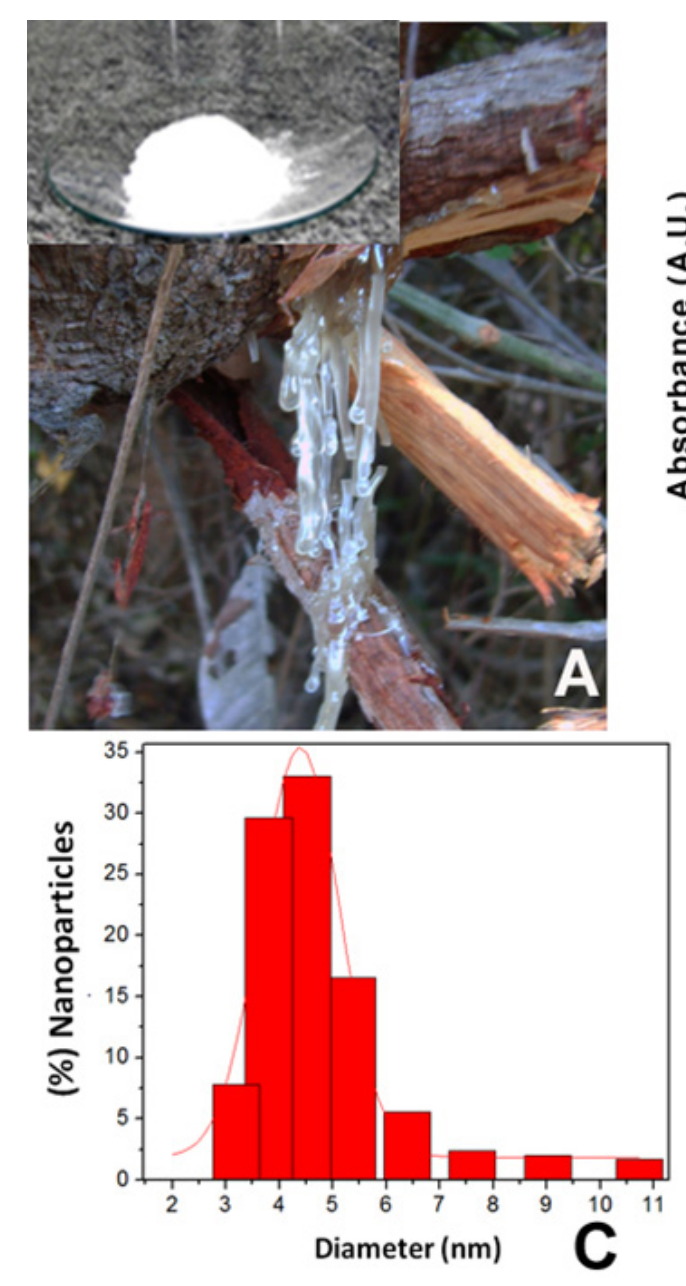
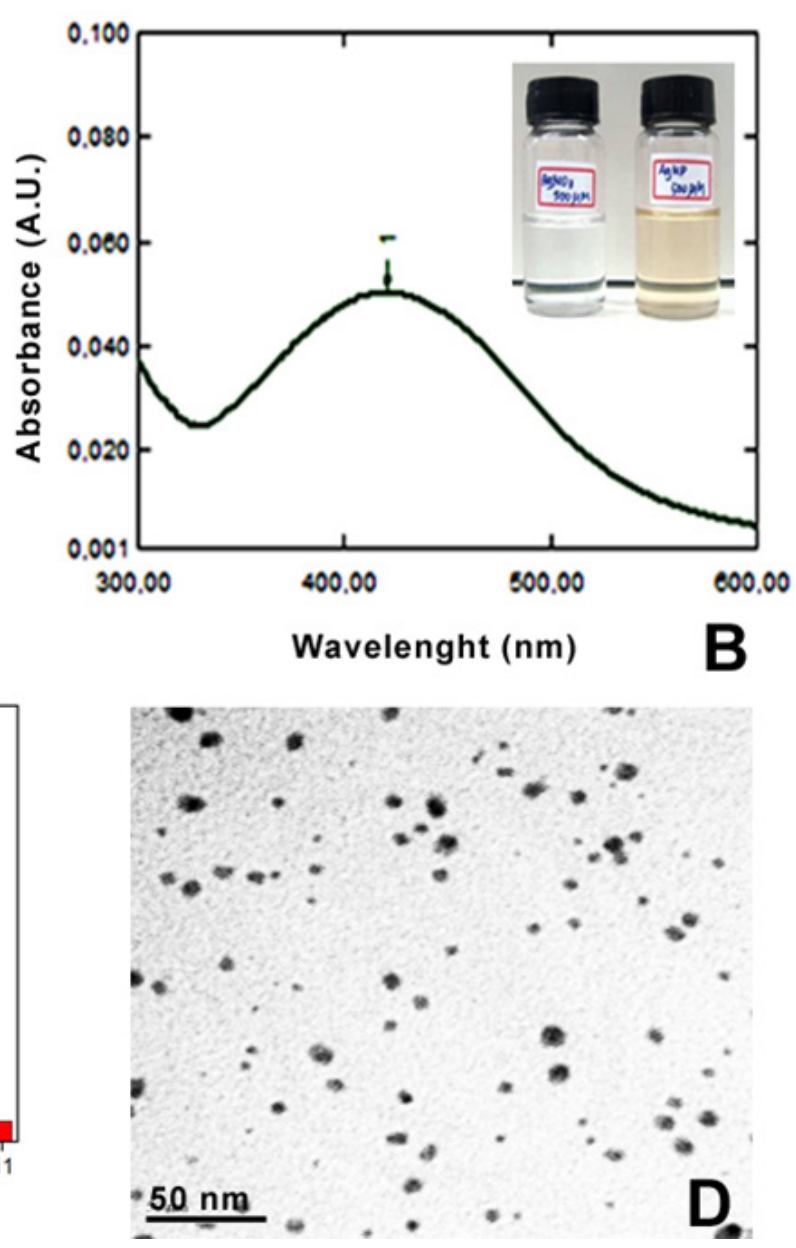

In this paper, we show that the heteropolysaccharide isolated from the cashew gum acts as a reducing and stabilizing agent in the synthesis of AgNPs. Despite the strong stabilizing potential of cashew gum, the apparent low yield in the conversion $\mathrm{Ag}^{+}$into $\mathrm{Ag}^{\circ}$ can be correlated to a low potential reducing this natural product when using this new green synthesis route. However, the synthesis shown has the characteristic of being fast and low cost. Previous studies have shown that natural gums may have a greater reducing potential, however through routes that include steps such as use of autoclave [10] that can alter the characteristics of natural products; or routes involving reactions with very long durations [24].

Nanoparticle preparation with biopolymers has several advantages over conventional synthetic chemical agents such as the presence of macromolecular chains of these biopolymers that posses a large number of hydroxyl groups that can complex well with the metal ion [4]. The natural polysaccharides may also possess negatively charged carboxyl groups, which can electrostatically interact with $\mathrm{Ag}^{+}$ions to form a complex as the part of $\mathrm{Ag}$ nanostructure [25]. 
We selected, cataloged and standardized bacterial strains with significant clinical importance in this study. These microorganisms are responsible for numerous diseases, cases of hospital infection, colonization of medical devices, and have the ability to acquire resistance [26]. Furthermore, they are strains commonly used in studies of antibacterial activity of AgNPs [10,16,19].

The MIC of an antibacterial agent for a given organism is the lowest concentration required to inhibit the growth of a bacterial inoculum in a standard test. The MBC is the minimal concentration of antibiotic that kills the inoculum and can be determined from broth dilution MIC tests by subculturing to agar media without antibiotics. An agent is usually regarded as bactericidal if the MBC is no more than four times the MIC [27]. In relation to the MICs observed for the Gram-positive bacteria, there was a greater susceptibility to $S$. epidermidis. For this group of bacteria, there was no difference in MIC between AgNPs and $\mathrm{AgNO}_{3}$ (Table 1). For the Gram-negatives, AgNPs presented a MIC of $6.75 \mu \mathrm{gAg} / \mathrm{mL}$ for $E$. coli ATCC 35218, half the value obtained with $\mathrm{AgNO}_{3}(13.5 \mu \mathrm{gAg} / \mathrm{mL}) . \mathrm{AgNPs}$ also presented a MIC of $3.37 \mu \mathrm{gAg} / \mathrm{mL}$ for $P$. aeruginosa (the lowest observed in the Gram-negative bacteria), it also presenting a higher potency compared to $\mathrm{AgNO}_{3}(\mathrm{MIC}$ of $6.75 \mu \mathrm{gAg} / \mathrm{mL}$ ) (Table 1). In relation to MBC test, E. coli ATCC 35218 again showed a higher susceptibility to AgNPs (CBM of $6.75 \mu \mathrm{gAg} / \mathrm{mL})$ than to $\mathrm{AgNO}_{3}(\mathrm{CBM}$ of $13.5 \mu \mathrm{gAg} / \mathrm{mL})$ and it showed identical results to the MIC test for both agents (Table 1).

Table 1. Minimum inhibitory concentrations (MICs) and minimum bactericidal concentrations of AgNPs $(\mu \mathrm{gAg} / \mathrm{mL}), \mathrm{AgNO}_{3}(\mu \mathrm{gAg} / \mathrm{mL})$ and standard antibiotics $(\mu \mathrm{g} / \mathrm{mL})$.

\begin{tabular}{|c|c|c|c|c|c|}
\hline \multirow[t]{2}{*}{ Bacterial strains } & \multicolumn{2}{|c|}{ AgNPs } & \multicolumn{2}{|c|}{$\mathrm{AgNO}_{3}$} & \multirow{2}{*}{$\begin{array}{c}\text { Antibiotic } \\
\text { MIC } \\
\end{array}$} \\
\hline & MIC & MBC & MIC & MBC & \\
\hline $\begin{array}{l}\text { S. epidermidis } \\
\text { ATCC } 12228\end{array}$ & 3.37 & $>27$ & 3.37 & $>27$ & $\begin{array}{c}\text { Oxacilin } \\
<0.5\end{array}$ \\
\hline $\begin{array}{l}\text { S. aureus } \\
\text { ATCC } 29213\end{array}$ & 13.5 & $>27$ & 13.5 & $>27$ & $\begin{array}{c}\text { Oxacilin } \\
<0.5\end{array}$ \\
\hline $\begin{array}{l}\text { S. aureus COL } \\
\text { MRSA }\end{array}$ & 13.5 & 13.5 & 13.5 & 13.5 & $\begin{array}{c}\text { Vancomycin } \\
1\end{array}$ \\
\hline $\begin{array}{l}\text { E. faecalis } \\
\text { ATCC } 29212\end{array}$ & 13.5 & 27 & 13.5 & $>27$ & $\begin{array}{c}\text { Vancomycin } \\
2\end{array}$ \\
\hline $\begin{array}{l}\text { E. coli } \\
\text { ATCC } 25922\end{array}$ & 6.75 & 6.75 & 6.75 & 6.75 & $\begin{array}{l}\text { Meropenen } \\
\quad<0.5\end{array}$ \\
\hline $\begin{array}{l}\text { E. coli } \\
\text { ATCC } 35218\end{array}$ & 6.75 & 6.75 & 13.5 & 13.5 & $\begin{array}{l}\text { Meropenen } \\
\quad<0.5\end{array}$ \\
\hline $\begin{array}{l}\text { K. pneumoniae } \\
\text { ATCC } 700603\end{array}$ & 6.75 & 6.75 & 6.75 & 6.75 & $\begin{array}{l}\text { Meropenen } \\
\quad<0.5\end{array}$ \\
\hline $\begin{array}{l}\text { P.aeruginosa } \\
\text { ATCC } 27853\end{array}$ & 3.37 & 6.75 & 6.75 & 6.75 & $\begin{array}{l}\text { Meropenen } \\
\quad<0.5\end{array}$ \\
\hline
\end{tabular}

The higher susceptibility of Gram-negative bacteria to AgNPs may be due to the rapid internalization of the nanoparticles through their thin cell walls, which are low in peptidoglycan, and thus inactivating and/or altering the protein structure, leading to cell death. Due to Gram-positive bacteria possessing a cell wall containing a thick layer of peptidoglycan, it becomes more difficult to 
absorb AgNPs in the cytoplasm, which might explain the need for a higher concentration of agent being required for antibacterial action [22].

In all tested bacteria, there was no antibacterial activity of cashew gum, whose concentrations were tested at dilutions concomitant of their concentration in the solution of AgNPs produced. The MICs of antibiotics patterns presented in accordance with standards established by the Clinical Laboratory Standards Institute [28] (Table 1).

The result of the determination of minimum bactericidal concentration for $S$. aureus ATCC 29212 and S. epidermidis was greater than $27 \mu \mathrm{gAg} / \mathrm{mL}$ (the highest concentration tested) (Table 1). However, a smaller number of colonies resulting from the effect of AgNPs were observed when compared to the results obtained by $\mathrm{AgNO}_{3}$ for all tested concentrations (Figure 2). In this case, in all Gram-positives bacteria, AgNPs caused a reduction higher than or equal to $3 \log _{10} \mathrm{CFU} / \mathrm{mL}$ in relation to the inoculum (Figure 3), which also characterizes bactericidal activity [27].

Figure 2. Example in which the antibacterial activity of $\mathrm{AgNPs}$ was greater than $\mathrm{AgNO}_{3}$. Effect of $13.5 \mu \mathrm{gAg} / \mathrm{mL}$ of (1) AgNPs and (2) $\mathrm{AgNO}_{3}$ on Staphylococcus aureus ATCC 29213 observed in the CBM test. (SA) Sterile Agar.

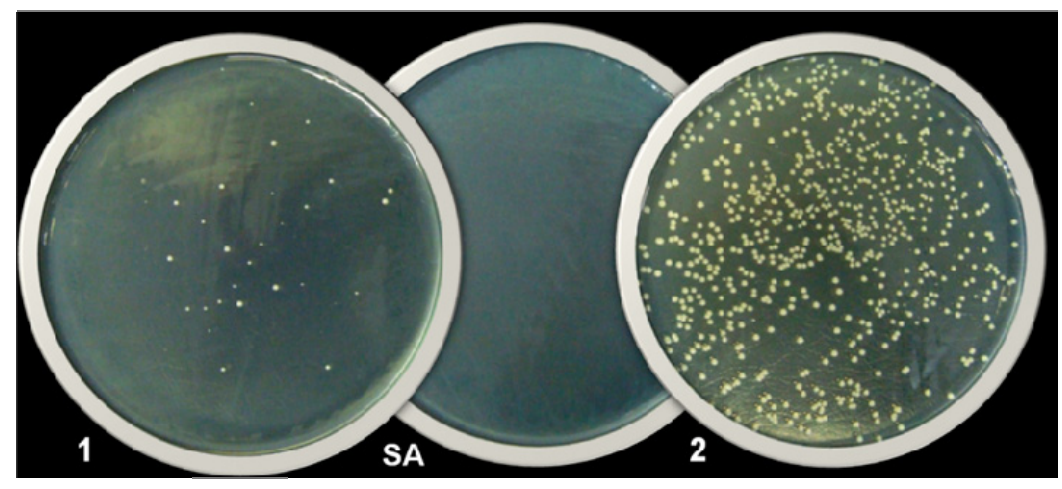

Figure 3. Antibacterial effect of 13.5 and $27 \mu \mathrm{gAg} / \mathrm{mL}$ of $\mathrm{AgNPs}$ and $\mathrm{AgNO}_{3}$ on: (A) Staphylococcus epidermidis; (B) Staphylococcus aureus ATCC 29123 and (C) Enterococcus faecalis, in an exposure time of $24 \mathrm{~h}$. Each column represents the mean \pm SEM of $\mathrm{CFU} / \mathrm{mL}$.
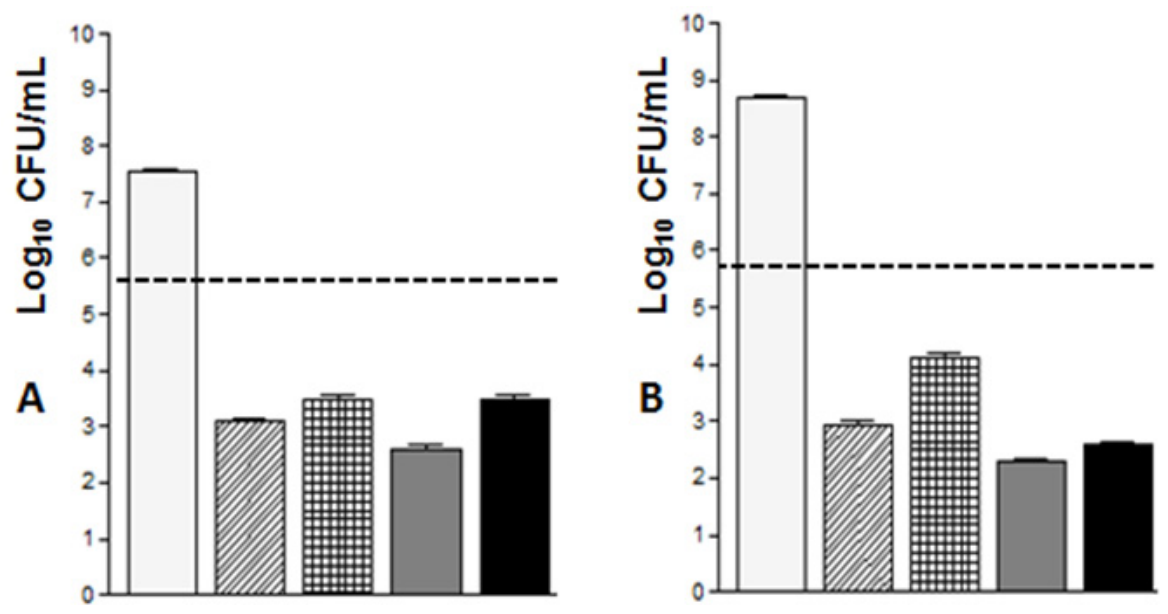
Figure 3. Cont.
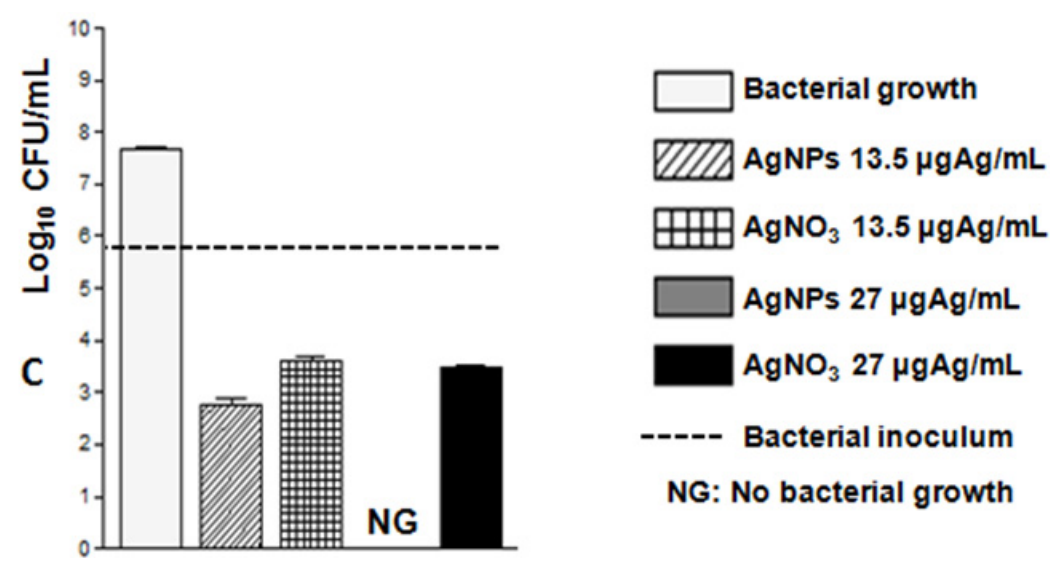

Tran et al. [19] cited as to the possible action mechanisms of AgNPs: $\mathrm{Ag}^{+}$ions are supposed to bind to sulfhydryl groups, which lead to protein denaturation by reducing disulfide bonds; $\mathrm{Ag}^{+}$can complex with electron donor groups containing sulfur, oxygen, or nitrogen that are normally present as thiols or phosphates on amino acids and nucleic acids; AgNPs have been found to attach to the surface of the cell membrane and disrupt its function, penetrate bacteria, and release $\mathrm{Ag}^{+} ; \mathrm{AgNPs}$ target the bacterial membrane, leading to a dissipation of the proton motive force.

According to Chatterje et al. [29], among the different nanomaterials with antibacterial properties, metal nanoparticles are the most potent and promising agents. However, to use them commercially, detailed investigations on the mechanism of microbial death and toxicity in mammalian cells must be performed. In this study, we performed a preliminary study of the cytotoxicity of AgNPs in order to investigate its effect on VERO cells, recommended for studies of cytotoxicity of biomaterials by international norms [30].

Initially a qualitative assessment of the effect of agents on the viability of cell culture through a morphological analysis of cells using trypan blue dye was performed, in which cells with damages in membrane were stained. Figure 4 shows photomicrographs obtained from the standard view of the same field focal and localized region in the center wells of the plate. Cashew gum, at the highest concentration used $(750 \mu \mathrm{g} / \mathrm{mL})$, did not change the morphology of the cells in comparison to the one observed in the control group. However, solutions of $\mathrm{AgNPs}$ and $\mathrm{AgNO}_{3}$ caused an increase in the number of damaged cells as a result of higher concentrations. Furthermore, in the cell culture wells subjected to the action of these agents, the appearance of colored blackish circular structures was observed, especially in higher concentrations, with seemingly larger amounts in cells treated with $\mathrm{AgNO}_{3}$. It is likely that these structures result from the formation of silver crystals reduced due to possible reducing agents present in the cell culture medium such as carbohydrates and proteins (Figure 4).

Figure 5 shows the results of the quantitative assessment of cytotoxicity of the tested agents. It was found that there was no reduction in the number of adhered cells in the group treated with cashew gum. The AgNPs action did not cause statistically significant decrease in the percentage of adhered cells from 3.37 to $13.5 \mu \mathrm{gAg} / \mathrm{mL}$. However, the highest concentration of $\mathrm{AgNPs}$ and $\mathrm{AgNO}_{3}(27 \mu \mathrm{gAg} / \mathrm{mL})$ resulted in a cell adherence of about $25 \%$, which is the concentration that presented significant cytotoxicity to VERO cells. 
Figure 4. Morphological evaluation of VERO cells in staining with trypan blue after 48 hours of incubation, exposed to the action of the agents analyzed: (A) growth control; (B) Cashew gum-750 $\mu \mathrm{g} / \mathrm{mL}$; (C) AgNPs-6.75 $\mu \mathrm{gAg} / \mathrm{mL}$; (D) $\mathrm{AgNO}_{3}-6.75 \mu \mathrm{gAg} / \mathrm{mL}$; (E) AgNPs-13.5 $\mu \mathrm{gAg} / \mathrm{mL}$; (F) $\mathrm{AgNO}_{3}-13.5 \mu \mathrm{gAg} / \mathrm{mL}$; (G) AgNPs-27 $\mu \mathrm{gAg} / \mathrm{mL}$; (H) $\mathrm{AgNO}_{3}-27 \mu \mathrm{gAg} / \mathrm{mL}$.
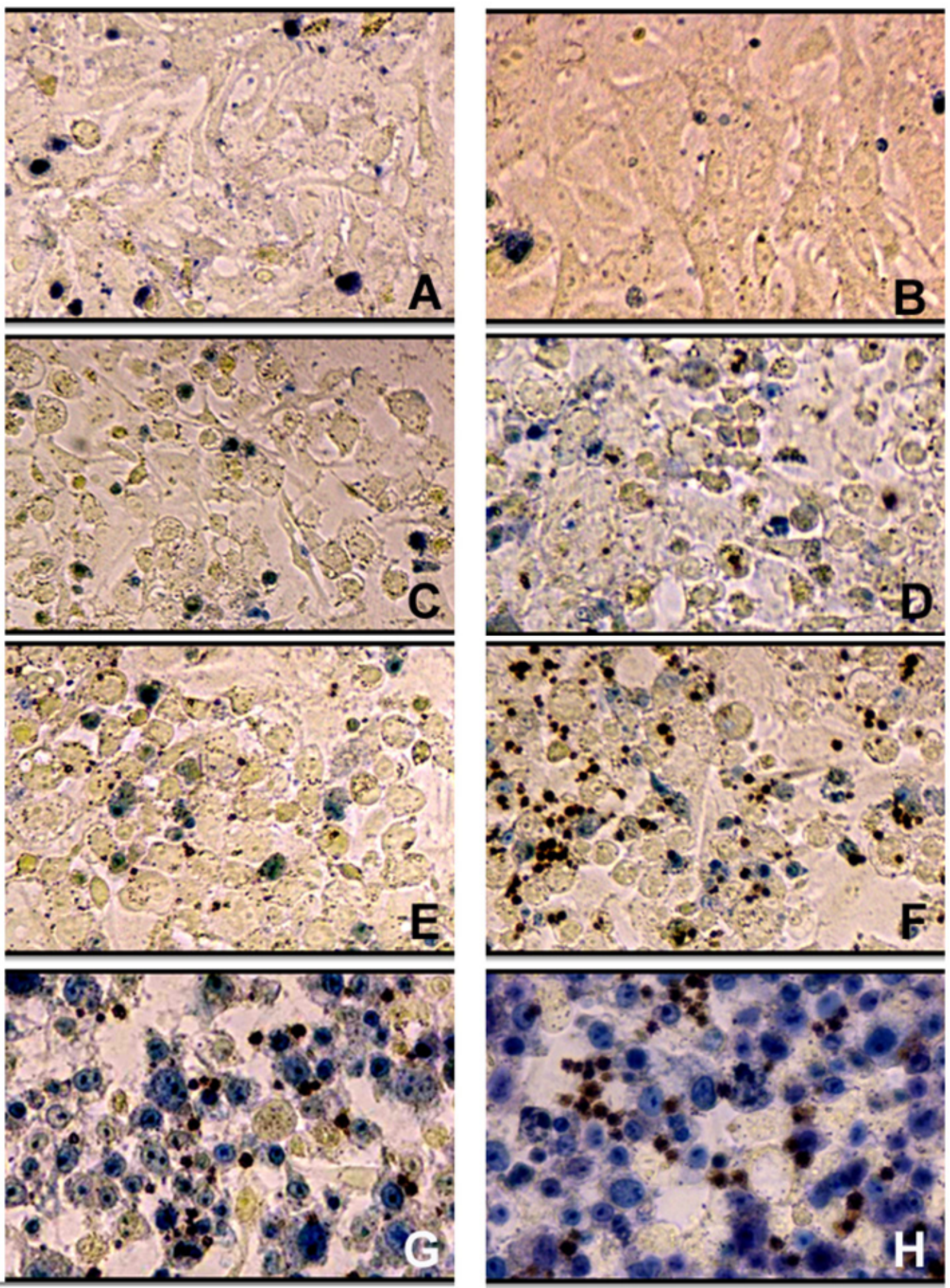
Figure 5. Effect of cashew gum, $\mathrm{AgNO}_{3}$ e AgNPs on VERO cell adherence, after 48 hours of exposure. Each column represents the mean \pm SEM $* p<0.05, * * * p<0.001$ compared to the control group of cell growth (One-way analysis of variance followed of Dunnett's multiple comparison test using GraphPad Prism 4.0).

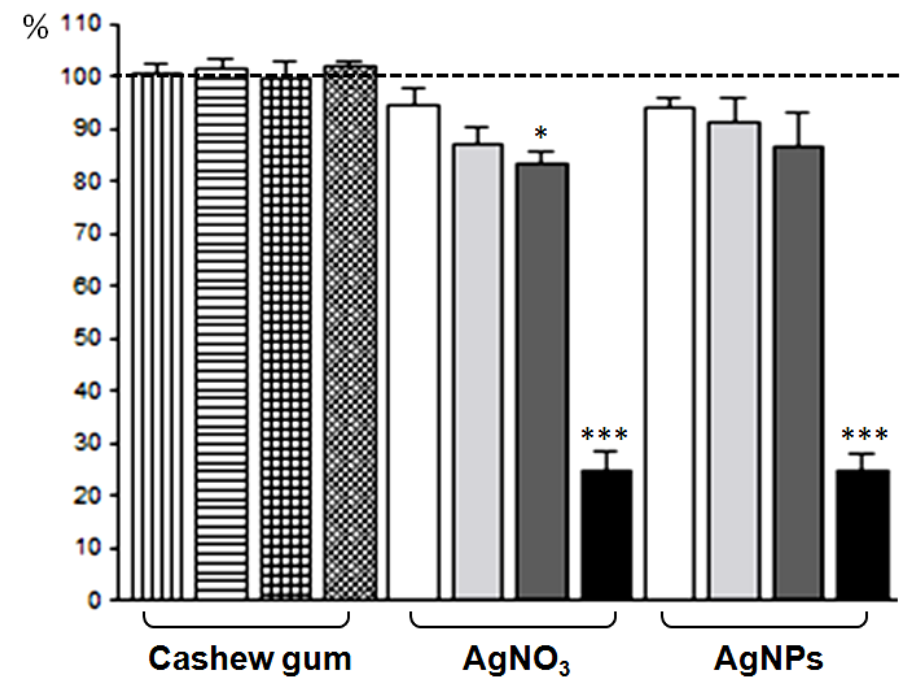

एس] $93.75 \mu \mathrm{g} / \mathrm{mL}$ 已 $187.5 \mu \mathrm{g} / \mathrm{mL}$ 世再 $375 \mu \mathrm{g} / \mathrm{mL}$ min $750 \mu \mathrm{g} / \mathrm{mL}$

$\square 3.37 \mu \mathrm{gAg} / \mathrm{mL}$

$6.75 \mu \mathrm{gAg} / \mathrm{mL}$

$13.5 \mu \mathrm{gAg} / \mathrm{mL}$

$27 \mu \mathrm{gAg} / \mathrm{mL}$

--- Cellular growth

It was found, however, that the minimum inhibitory concentrations of all bacteria tested are in a concentration range of AgNPs (between 3.37 and $13.5 \mu \mathrm{gAg} / \mathrm{mL}$ ) in which there was no observed significant cytotoxic activity compared to the control. This fact is more significant in respect to Gram-negative bacteria, for which the bactericidal concentration values are also described in the same range.

This work focused primarily in the development of a new green synthesis route and application of this nanomaterial as an antibacterial solution. We performed some preliminary tests of cytotoxicity in cultured mammalian cells. However, subsequent studies related to the cytotoxicity of these cashew gum-based silver nanoparticles should be performed, such as checking its influence on cellular metabolism and its genotoxicity on VERO cells as well in other cell lines.

The AgNPs presented in this study were carried out by means of a fast and low cost "Green synthesis" using an accessible, sustainable and renewable natural product. It is too early to speculate how the formation of cashew gum-based AgNPs may be used in the prevention or in the control of bacterial infections. However the amount of biotechnological products containing AgNPs in its composition is increasing every day. For example it is being used in impregnation of wound dressings, medical devices, dental materials, fabrics, among others $[8,31,32]$, besides the combination with antibiotics for the observation of a synergistic antibacterial effect $[16,17]$. Further studies may be conducted with varied physicochemical parameters to improve the efficiency of the AgNPs reaction synthesis with cashew gum, which could increase the antibacterial activity and reduce the cytotoxic effects.

\section{Experimental Section}

\subsection{Cashew Gum Purification}

The cashew gum purification was performed following the method of Silva [33] with some modifications. The gum collected from Anacardium occidentale L. was solubilized in ultrapure-water 
at room temperature in a concentration of $5 \% \mathrm{w} / \mathrm{v}$, under magnetic stirring for $12 \mathrm{~h}$. After its filtration to remove impurities, the $\mathrm{pH}$ of the solution was adjusted to 7 and then $\mathrm{NaCl} \mathrm{P.A.,} \mathrm{in} \mathrm{proportion} \mathrm{to} \mathrm{the}$ gum, was added to obtain the polymer as a sodium salt. After stirring it, for the solubilization of the salt, the gum was precipitated with ethanol P.A. at the proportion of 1:4 v/v (solution of gum:ethanol), vacuum filtered and dried. Then the product was dissolved again in a concentration of $5 \% w / v$ and subjected two more times to the same procedure described above, except for the addition of $\mathrm{NaCl}$, which has its amount halved for the first repetition and then reduced to zero.

\subsection{Synthesis and Characterization of Silver Nanoparticles}

Solutions of silver nitrate $\left(\mathrm{AgNO}_{3}\right) 1 \mathrm{mM}$ and cashew gum $(0.3 \% \mathrm{w} / \mathrm{v})$, previously solubilized under stirring for 12 hours were prepared. The synthesis was performed in an open glass reactor with magnetic stirring, in temperature-controlled water bath at $78 \pm 2{ }^{\circ} \mathrm{C}$ by mixing the two solutions $(1: 1 \mathrm{v} / \mathrm{v})$ for $60 \mathrm{~min}$. The yellowish color of the silver nanoparticles was observed by digital camera and the synthesis of silver nanoparticles was monitored by UV-Vis-NIR scanning spectrophotometer (UV-3101 PC, Shimadzu, Japan) over the range of 300-600 nm. For the Transmission Electron Microscopy (TEM), a drop of colloidal solution consisting of silver nanoparticles was dispensed directly onto a carbon-coated copper grid and allowed to dry completely in a vacuum desiccator. The images were obtained using a JEOL transmission electron microscope (Model JEM 2100, Tokyo, Japan) equipped with an EDX attachment at $200 \mathrm{kV}$. The hydrodynamic diameter was measured by dynamic light scattering with laser with a wavelength of $633 \mathrm{~nm}$ and afixed scattering angle of $90^{\circ}$. Particle size was measured considering the particle as being spherical. Each sample was measured three times so as to have three replicate samples.

\subsection{Evaluation of Antibacterial Activity of AgNPs}

To study the antibacterial properties of AgNPs, four strains of Gram-positive bacteria were selected: Staphylococcus aureus ATCC 29213; Methicillin-Resistant S. aureus COL (MRSA) [34]; Staphylococcus epidermidis ATCC 12228 and Enterococcus faecalis ATCC 29212; and four Gram-negatives were also selected: Escherichia coli ATCC 25922; Escherichia coli ATCC 35218; Pseudomonas aeruginosa ATCC 27853 and Klebsiella pneumoniae ATCC 700603. The microorganisms were cultured in Mueller-Hinton agar at $37{ }^{\circ} \mathrm{C}$ for 24 hours in aerobic conditions. Then a suspension of bacterial strains with an optical density of McFarland of $0.5\left(1 \times 10^{8} \mathrm{CFU} / \mathrm{mL}\right)$ was made in an isotonic sodium chloride $0.85 \%$ solution. Later in time, this solution was diluted ten times $\left(1 \times 10^{7} \mathrm{CFU} / \mathrm{mL}\right)$ and used as inoculum in the experiments described below.

Determination of the Minimum Inhibitory Concentration (MIC) and Minimum Bactericidal Concentration (MBC) of AgNPs

MIC was determined according to CLSI [28] with some adaptations using 96-well microdilution plate where the strains (concentration of $5 \times 10^{5} \mathrm{CFU} / \mathrm{mL}$ ) were exposed to two-fold dilution series of the AgNPs ranging from 27 to $0.42 \mu \mathrm{gAg} / \mathrm{mL}$. The same procedure was used to determine the MIC of the following controls: cashew gum, $\mathrm{AgNO}_{3}$, and standard antibiotics effective against the bacterial 
strains tested. At the end of the microdilution, concentrations ranged from 27 to $0.42 \mu \mathrm{gAg} / \mathrm{mL}$ for $\mathrm{AgNO}_{3} ; 750$ to $5.85 \mu \mathrm{g} / \mathrm{mL}$ for cashew gum and 32 to $0.25 \mu \mathrm{g} / \mathrm{mL}$ for antibiotics. Sterile Mueller-Hinton broth was used as the negative control and inoculated broth was used as the positive control. MIC was defined as the lowest concentration of agent that restricted growth to a level lower than 0.05 at $600 \mathrm{~nm}$ (no visible growth).

For the MBC determination, aliquots $(50 \mu \mathrm{L})$ from all wells with concentrations higher or equal to the MIC concentrations were sub-cultured on Mueller-Hinton agar. MBC was defined as the lowest concentration that enabled no growth on the agar (99.9\% kill). If bacterial growth occurred, the units forming colonies (UFC) were counted in order to observe a possible decrease in their number relative to the increased concentration of the agent tested. All assays were performed in triplicate.

\subsection{Evaluation of Cytotoxicity of AgNPS}

Vero mammalian cells (African green monkey kidney fibroblast) ATCC CCL-81 were used in this study. For a short duration, Vero cells maintained in Leibovitz L-15 (VITROCELL, Campinas, Brazil) and supplemented with $10 \%$ heat-inactivated calf serum were seeded at a density of $5 \times 10^{4}$ cells per well into 96-well culture microplate. Cells groups treated with different concentrations of AgNPs (ranging from 27 to $3.37 \mu \mathrm{gAg} / \mathrm{mL}$ ), $\mathrm{AgNO}_{3}$ (27 to $3.37 \mu \mathrm{gAg} / \mathrm{mL}$ ) and cashew gum (750 to $93.75 \mu \mathrm{g} / \mathrm{mL}$ ), as well as a control group of cell growth, were incubated at $37{ }^{\circ} \mathrm{C}$ in a $5 \% \mathrm{CO}_{2}$ atmosphere. After 48 hours of incubation, trypan blue dye was applied to all wells and after 15 min the content of the wells was gently aspirated and the plate was taken for microscopic observation under $400 \times$ magnification (NIKON TS 100).

In the next step, crystal violet dye was applied to the wells for $10 \mathrm{~min}$, then the content of the wells was removed and the plate was washed with water. After drying at room temperature, the plate was again taken to observation by microscopy observed under $400 \times$ magnification and the digital images of the remaining adhered cells were captured using NIS-Elements F software. The captured images were standardized to cover the central area of each well and through them the percent of adhered cells was calculated in relation to the control group. The results were expressed as the mean $\pm \mathrm{SEM}$ and analysed by one-way analysis of variance followed by Dunnett's multiple comparison test. Differences between groups and control were considered significant when $p<0.05$ (GraphPad Prism software 4.0).

\section{Conclusions}

Cashew gum-based silver nanoparticles showed antibacterial activity with greater effect on Gram-negative bacteria. Cytotoxic effect on VERO cells at the highest concentration of AgNPs evaluated was observed, showing, at this concentration, results similar to those generated by $\mathrm{AgNO}_{3}$. There was no significant cytotoxicity at the concentrations of AgNPs necessary to cause bactericidal effects on Gram-negative bacteria.

\section{Acknowledgments}

This study received financial support from Conselho Nacional de Desenvolvimento Científico e Tecnológico (CNPq, Brazil, "Consolidação Novos Campi, 2009” processo 503495/2009-3 and Casadinho/PROCAD), Nanobiomed Network CAPES, Farmácia GALENO, ABRID (Associação 
Brasileira das Empresas de Tecnologia em Identificação Digital) and FENAPPI (Federação Nacional dos Profissionais em Papiloscopia e Identificação). The authors are grateful to Lucas Souza Kückelhaus for reviewing the English language of the manuscript.

\section{References}

1. Nicaido, H. Multidrug resistance in bacteria. Ann. Rev. Biochem. 2009, 78, 119-146.

2. Guimarães, D.O.; Momesso, L.S.; Pupo, M.T. Antibióticos: Importância terapêutica e perspectivas para a descoberta e desenvolvimento de novos agentes. Quim. Nova 2010, 33, 667-679.

3. Huh, A.E.; Kwon, Y.J. "Nanoantibiotics": A new paradigm for treating infectious diseases using nanomaterials in the antibiotics resistant era. J. Control. Release 2011, 156, 128-145.

4. Mohanty, S.; Mishra, S.; Jena, P.; Jacob, B.; Sarkar, B.; Sonawane, A. An investigation on the antibacterial, cytotoxic, and antibiofilm efficacy of starch-stabilized silver nanoparticles. Nanomedicine 2012, 8, 916-924.

5. Fang, M.; Chen, J.; Xub, X.; Yang, P.; Hildebrand, H.F. Antibacterial activities of inorganic agents on six bacteria associated with oral infections by two susceptibility tests. Int. J. Antimicrob. Agents 2006, 27, 513-517.

6. Allaker, R.P. The use of nanoparticles to control oral biofilm formation. J. Dent. Res. 2010, 89, 1175-1186.

7. Dorjnamjin, D.; Ariunaa, M.; Shim, Y.K. Synthesis of silver nanoparticles using hydroxyl functionalized ionic liquids and their antimicrobial activity. Int. J. Mol. Sci. 2008, 9, 807-820.

8. Rai, M.; Yadav, A.; Gade, A.S. Silver nanoparticles as a new generation of antimicrobials. Biotechnol. Adv. 2009, 27, 76-83.

9. Chaloupka, K.; Malam, Y.; Seifalian, A.M. Nanosilver as a new generation of nanoproduct in biomedical applications. Trends Biotechnol. 2010, 28, 580-588.

10. Kora, A.J.; Sashidhar, R.B.; Arunachalam, J. Gum kondagogu (Cochlospermum gossypium): A template for the green synthesis and stabilization of silver nanoparticles with antibacterial application. Carbohydr. Polym. 2010, 82, 670-679.

11. Shukla, M.K.; Singh, R.P.; Reddy, C.R.K.; Bhavanath, J. Synthesis and characterization of agar-based silver nanoparticles and nanocomposite film with antibacterial applications. Bioresour. Technol. 2012, 107, 295-300.

12. Sharma, K.V.; Yngard, R.A.; Lin, Y. Silver nanoparticles: Green synthesis and their antimicrobial activities. Adv. Colloid Interface Sci. 2009, 145, 83-96.

13. Parashar, U.K.; Kumar, V.; Bera, T.; Saxena, P.S.; Nath, G.; Srivastava, S.K.; Giri, R.; Srivastava, A. Study of mechanism of enhanced antibacterial activity by green synthesis of silver nanoparticles Nanotechnology 2011, 22, doi:10.1088/0957-4484/22/41/415104.

14. Shameli, K.; Ahmad, M.B.; Jazayeri, S.D.; Sedaghat, S.; Shabanzadeh, P.; Jahangirian, H.; Mahdavi, M.; Abdollahi, I. Synthesis and characterization of polyethylene glycol mediated silver nanoparticles by the Green method. Int. J. Mol. Sci. 2012, 13, 6639-6650.

15. Sastri, M.; Ahmad, A.; Khan, M.I.; Kumar, R. Biosynthesis of metal nanoparticles using fungi and actinomycete. Curr. Sci. 2003, 85, 162-170. 
16. Shahverdi, A.R.; Fakhimi, A.; Shahverdi, H.R.; Minaian, S. Synthesis and effect of silver nanoparticles on the antibacterial activity of different antibiotics against Staphylococcus aureus and Escherichia coli. Nanomedicine 2007, 3, 168-171.

17. Fayaz, M.H.; Balaji, K.; Girilal, M.; Yadav, R.; Kalaichelvan, P.H.; Venketesan, R. Biogenic synthesis of silver nanoparticles and their synergistic effect with antibiotics: A study against Gram-positive and Gram-negative bacteria. Nanomedicine 2010, 6, 103-109.

18. Wei, D.; Sun, W.; Qian, W.; Ye, Y.; Mac, X. The synthesis of chitosan-based silver nanoparticles and their antibacterial activity. Carbohydr. Res. 2009, 344, 2375-2382.

19. Tran, V.V.; Tran, L.D.; Cham, T.B.; Vu, H.D.; Nguyen, T.N.; Pham, D.G. Nguyen, P.X. Synthesis, characterization, antibacterial and antiproliferative activities of monodisperse chitosan-based silver nanoparticles. Colloids Surf. A 2010, 360, 32-40.

20. Krishnaraj, C.; Jagan, E.G.; Rajasekar, S.; Selvakumar, P.; Kalaichelvan, P.T.; Mohan, N. Synthesis of silver nanoparticles using Acalypha indica leaf extracts and its antibacterial activity against water borne pathogens. Colloids Surf. B 2010, 76, 50-56.

21. Saxena, A.; Tripathi, R.M.; Zafar, F.; Singh, P. Green synthesis of silver nanoparticles using aqueous solution of Ficus benghalensis leaf extract and characterization of their antibacterial activity. Mater. Lett. 2012, 67, 91-94.

22. Venkatpurwar, V.; Pokharkar, V. Green synthesis of silver nanoparticles using marine polysaccharide: Study of in-vitro antibacterial activity. Mater. Lett. 2011, 65, 999-1002.

23. De Paula, R.C.M.; Healthy, F.; Budd, P.M. Characterisation of Anacardium occidentale: Exudate polysaccharide. Polym. Int. 1998, 45, 27-35.

24. Mohan, Y.M.; Raju, K.M.; Sambasivudu, K.; Singh, S.; Sreedhar, B. Preparation of Acacia-stabilized silver nanoparticles: A green approach. J. Appl. Polym. Sci. 2007, 106, 3375-3381.

25. Abdel-Mohsen, A.M.; Hrdina, R.; Burgert, L.; Krylova, G.; Abdel-Rahman, R.M.; Krejcova, A.; Steinhart, M.; Benes, L. Green synthesis of hyaluronan fibers with silver nanoparticles. Carbohydr. Polym. 2010, doi:10.1016/j.carbpol.2012.03.022.

26. Toledo, P.V.M.; Arend, L.N.; Pilonetto, M.; Costa Oliveira, J.C.; Luhm, K.R. Surveillance programme for multidrug-resistant bacteria in healthcare-associated infections: An urban perspective in South Brazil. J. Hosp. Infect. 2012, 80, 351-353.

27. French, G.L. Bactericidal agents in the treatment of MRSA infections-the potential role of daptomycin. J. Antimicrob. Chemother. 2006, 58, 1107-1117.

28. CLSI-Clinical Laboratory Standards Institute. Methods for dilution antimicrobial susceptibility test for bacteria that grow aerobically. Available online: http:/www.clsi.org/source/orders/ free/m07-a9.pdf (accessed on 18 September 2012).

29. Chatterjee, A.K.; Sarkar, R.K.; Chattopadhyay, A.P.; Aich, P.; Chakraborty, R.; Basu, T. A simple robust method for synthesis of metallic copper nanoparticles of high antibacterial potency against E. coli. Nanotechnology 2012, 23, doi:10.1088/0957-4484/23/8/085103.

30. Kirkpatrick, C.J. Biological testing of materials and medical devices: A critical view of current and proposed methodologies for biocompatibility testing: Cytotoxicity in vitro. Regulat. Aff. 1992, $4,13-32$. 
31. Monteiro, D.R.; Gorup, L.F.; Takamiya, A.S.; Ruvollo-Filho, A.C.; Camargo, E.R.; Barbosa, D.B. The growing importance of materials that prevent microbial adhesion: Antimicrobial effect of medical devices containing silver. Int. J. Antimicrob. Agents 2009, 34, 103-110.

32. Fontenoy, C.; Kamel, S.O. Silver in the medical devices/equipments: Marketing or real clinical interest? Pharmacien Hospitalier 2010, 45, 131-140.

33. Silva, D.A.; Feitosa, J.P.A.; Paula, H.C.B.; Paula R.C.M. Synthesis and characterization of cashew gum/acrylic acid nanoparticles. Mater. Sci. Eng. C 2009, 29, 437-444.

34. Jevons, M.P. “Celbenin”-resistant staphylococci. Br. Med. J. 1961, 1, 124-125.

(C) 2013 by the authors; licensee MDPI, Basel, Switzerland. This article is an open access article distributed under the terms and conditions of the Creative Commons Attribution license (http://creativecommons.org/licenses/by/3.0/). 